\title{
Die eksegetiese proses: verleentheid of geleentheid
}

\author{
JA VAN BILJON
}

\section{INLEIDING}

Die eksegetiese proses in die praktiese situasie van die gemeente word as invalshoek geneem. In 'n poging om die onderwerp sinvol te hanteer sal naas die preskriptiewe element ook die diagnostiese aspek uitgelig word. Dit is nogal opvallend dat predikers soms die rampspoedige neiging het om al hulle energie in ' $n$ minder mate te wy aan 'n soekende penetrasie van die gegewene, maar eerder hulle energie verspil om die gegewe dogma, die gegewe instituut, die gegewe Christelike "common sense" te bestuur en dit aan mense deur te gee. Gevolglik bly dit 'n aksiomatiese waarheid dat 'n preskripsie meer hanteerbaar is as 'n diagnose, want ' $n$ diagnose beskryf die kwaliteit van die gegewene en indirek dié se bestaansmoontlikheid.

\subsection{Die relasie eksegese en prediking}

Elke mensewoord wat pretendeer om prediking te wees is by voorbaat verplig om by die Skrif te begin, want prediking is wesenlik uitleg en toepassing van 'n teks of 'n perikoop. Geen profesie is ' $n$ saak van eie uitlegging nie. Daarom is prediking alleen prediking as dit die Skrif reg uitlê. Die regte uitleg is alleen moontlik deur noukeurige ondersoek en navorsing na die werklike bedoeling van die Heilige Gees in die Skrifte. Slegs in ooreenstemming met hierdie werklike bedoeling van die Heilige Gees, kan die prediking as verklaring van die Skrif reg sê wie Jesus Christus is, watter weldade Hy aan die mense bewys het en hoe $\mathrm{Hy}$ reg deur die mense gedien kan word. Slegs in hierdie onlosmaaklike binding aan die Skrif as die outentieke getuienis aangaande Jesus Christus is die prediking charisma, genadegawe aan die Kerk².

Dié gegewe aanvangspunt is essensieel vir 'n homileet, want 'n onmisbare voorwaarde vir prediking is dat dit uitleg van ' $n$ teks is. Dit moet egter nie verstaan word asof prediking eksegese is nie. Immers noukeurig-wetenskaplike eksegese sê: Dit is die bedoeling 
van wat hier of daar geskrywe staan en dit is 'n onmisbare voorwaarde omdat dit in Bybels-verantwoorde prediking die boodskap wat aan die gemeente gekommunikeer moet word, verskaf. JI de Wet sê: "Kerklik gesproke is die feit dat die Kerk moet preek, die rede waarom eksegese beoefen word"2 . Op verantwoordelike wyse moet die kerk se boodskap, sy preekstof vasgestel word, slegs wanneer dit gebeur het, kan die preekonderneming begin. "Die terminus ad quem van die eksegese is die terminus a quo van die prediking" ${ }^{\prime 3}$.

\section{2 'n Gegewe aanvangspunt}

Indien prediking as uitleg van 'n teks gedefinieer word, ontstaan aansienlike misverstand. Met die term "'n teks vir die prediking" word tradisioneel 'n betrokke genommerde "teksvers" bedoel. Die aanhangers van die nuwere eksegese-metodologie is van mening dat wanneer 'n genommerde teksvers as die vanselfsprekende aanvangspunt van die prediking as "teksvers" beskou word, ' $n$ atomistiese uitgangspunt gehandhaaf word wat nie met die struktuur van die betrokke Bybelgedeelte erns maak nie ${ }^{4}$.

Aan die ander kant beweer DJ Booysen die teks stel vir die homileet sekere grense. Hy kan dus nie sommer enige saak in die prediking te berde bring nie. Die aankondiging van 'n teks vir die prediking is die belofte aan die gemeente dat die homileet die Skrif gaan uitle $\hat{e}^{\mathbf{s}}$.

Waarskynlik ontstaan die misverstand omdat "teks" in homiletiese sin iets anders kan wees as in literêre $\sin$. Die eis van verantwoordelike homiletiek is dat oor 'n teks gepreek moet word. Daarmee word egter nie 'n genommerde sin of sinsnede bedoel nie. Die beoefenaars van die homiletiek hanteer nie 'n teks op 'n logosentriese wyse in sy konteks nie; inteendeel, onder teks verstaan die homiletiek 'n subtema wat binne 'n bepaalde konteks aan die orde gestel word'. Die homiletiek bedoel dan met 'n teks so ' $n$ eenheid wat binne die geheel van die evangeliese waarheid ' $n$ geldige subtema aan die orde stel. ' $n$ Bybelse tema verskaf die preekstof en vrywaar die prediking só van 'n preektema wat bestaan uit enige denkbare of ondenkbare oorsprong ${ }^{7}$. Kommunikatief is dit noodsaaklik dat die preektema aangekondig moet word, want die fokus die gemeente se aandag op die sentrale saak, stel die hoorders in staat om enkodering en dekodifikasie begrypend te volg en op sinvolle wyse te reageer ${ }^{8}$. Dit lei ook die predikant daartoe om sy 
preek rondom hierdie sentrale tema kommunikatief te struktureer, want uiteindelik is vir die slaagmoontlikheid van 'n preek nie die struktuur van die perikoop wat die preekstof oplewer, deurslaggewend nie, maar wel die struktuur van 'n preek wat die stof aan die gemeente deurgee?.

Dit impliseer, terwyl die prediker met die saaklike wetenskaplike eksegese besig is, moet hy voortdurend vra na wat die intensie van die teks is. Dit is van lewensbelang vir prediking wat een-lynig vanuit die eksegese na die hede beweeg ${ }^{10}$. Die eksegese moet die kerugmatiese spits, die eiesoortige blikrigting van die teks aandui ${ }^{11}$. In die formulering van die bepaalde gerigtheid van die teks, die eie aard, die "proprium" en die skopus of die spesifieke blikrigting ${ }^{12}$ van die teks, val 'n eksegetiese beslissing wat "die totale verdere rigting, gang en opbou van die preek bepaal"13. Die vasstelling van die intensie en die formulering van die skopus, die kerugmatiese skopus ${ }^{14}$ van die teks in sy eie eiendomlike konteks, is die taak en doel van die eksegese vanuit homiletiese gesigspunt.

\subsection{Homiletiese eksegese}

Indien die definisie: "Prediking is uitleg van 'n teks" verstaan word asof prediking eksegese is, kan die eksegetiese proses gepopulariseer word $^{15}$. Die tegniese terme van die eksegese word dan in gewone omgangstaal oorgesit. Die analise, hoofskopus, allerlei literêre, historiese en ander kritiese tegnikaliteite word dan vir die gemeente vertaal. Om die skyn van die houdbare objektivisme te vermy en die skyn van 'n preek te verwek, word voor aan hierdie sogenaamde "homiletiese eksegese" ' $n$ inleiding en agter 'n toepassing aangelas. aangelas.

Hierdie soort "homiletiese eksegese" gee meestal in die toepassing aanleiding tot moralisasie ${ }^{16}$. Vir prediking as dialogies-kommunikatiewe gebeure is die boodskap van primêre belang. Die vraag of dit oorspronklik by wyse van gelykenis of profesie of narratiewe materiaal of watter literère konstruksie ook al oorgelewer is, is irrelevant.

\subsection{Parafrastiese prediking}

Bogenoemde definisie gee ook aanleiding tot die misverstand dat daar net in populêre terme 'n parafrase van die inhoud van 'n 
perikoop gemaak word. 'n Teologiese kommentaar (meestal homileties) en 'n "toepassing" word ingevleg om 'n skyn van tegnikaliteit te verdoesel. Die effek is feitlik dieselfde as by die sogenaamde homiletiese eksegese, want ook dié preek is nie 'n kommunikatiefgestruktureerde preek nie $^{17}$

\section{TEKS-IMMANENTE EKSEGESE}

Die beoefening van homiletiek is van eksegetiese arbeid afhanklik ${ }^{\mathbf{1 8}}$, veral ten opsigte van die prinsipiële besinning. Gevolglik het die eksegese-metodeleer wat die insigte van die moderne taal- en literatuurwetenskap verdiskonteer 'n bepaalde invloed op die homiletiek.

Die prediking kan nooit as 'n blote herhaling of oorvertel van wat in die Bybel geskryf staan, beskou word nie, maar "die dienskarakter van die prediking soos dit na vore gebring word deur die relatiwiteit en afhanklikheid van die prediking ten opsigte van die getuienis van die Skrif, kan die beste omskrywe word deur die prediking te tipeer as kommentaar op en vertaling van die Skrif ${ }^{\prime \prime 19}$. Tereg sê De Wet dat die gedeelte waaroor gepreek word, onvoorwaardelik uitgelê moet word en hy waarsku teen die sogenaamde "kapstokprediking $^{\prime 20}$.

Teks-immanente eksegese bied vir die homileet die raamwerk van die sistematiese opbou van die gedagtes waaruit die betrokke Skrifgedeelte saamgestel is. Die onvoorwaardelike uitleg van die Skrif en die doelbewuste vermyding van "kapstokprediking" vereis dat daar groter erns gemaak moet word met die struktuur van die "teks". Inderdaad kan die raamwerk van die gedagtes wat die redevoeringsanalise bied, dien as die raamwerk waarbinne die "kommentaar"-werk en die "vertaal"-werk geskied".

Die sogenaamde "nuwe metode" is gekontroleerde eksegese. Dit is meer as 'n "semantiese metode" of selfs "semantiek" (immers semantiek is alleen één faset van die taalkunde wat bruikbaar is by die eksegese), dit is beslis nie slegs 'n "linguistiese metode" nie (asof die hantering van literatuurprodukte net ' $n$ saak is vir die linguistiek), maar ook is die metode nie slegs "struktuuranalise" (asof die struktuur van die teks die enigste saak is wat aandag verdien), die nuwere taalwetenskap het aan die homileet 'n pluralisme van metodes verskaf, sonder om 'n bepaalde metode te verabsoluteer. Die taak van die eksegeet is om aan die hand van verskeie metodiese fasette ${ }^{22}$ 'n teks te eksegetiseer. Die subjektiewe eklektiese 
werkwyse, nl. dat die aard van die teks die metode bepaal, word deur die metode pluralisme ondervang. Op die wyse het die homileet 'n gekontroleerde en toetsbare metodiese grondslag waarop hy kan werk. Daarin is verskeie metodes gereduseer tot metodiese aspekte met almal ewe goeie reg en noodsaak. Daar is onder hulle nie ' $n$ rangorde nie, maar wel 'n volgorde ${ }^{23}$. En dié bestaan in die onderskeid tussen sinchronie en diachronie.

Sinchroniese arbeid het te make met dit wat daar staan. Dié se metodiese fasette behels, perikoopafgrensing, tekskritiese ondersoek, struktuuranalise, Gattung, inhoudsondersoek. Historiese perspektiewe is nie nou ter sake nie, maar teks-immanente eksegese is bepalend.

Indien die homileet nou vasgestel het wat die inhoud van die perikoop beteken dan is die sinchroniese arbeid verrig. Twee aspekte moet dan aandag geniet. Eerstens moet die tradisiemateriaal ondersoek word en die beligting van die teks met historiese perspektiewe. Die ontwikkeling en historiese verloop van 'n teks wat so ondersoek word, is die diachroniese werk wat verrig word. Die laaste metodefaset heet redaksionele ondersoek ${ }^{24}$. Die moontlikheid word hier ondersoek of die latere redakteurs die verskillende eenhede in groter stukke verwerk het. Historiese perspektiewe is dan relevant.

Dit blyk volgens die metodiese fasette dat die diachronie alleen op grond van die sinchronie bedryf word. Dit impliseer: die homileet kan alleen vasstel wat die geskiedenis van 'n woord se betekenis is (diachronie), indien hy die verskillende voorkomste van daardie woord in verskillende tekste bestudeer het soos hulle werklik daar gebruik word (sinchronie). Dit beteken, historiese aspekte kan nooit die uitgangspunt in die eksegese wees nie. Sulke aspekte is wel van belang, maar mag alleen volg nadat ons die teks soos hy daar staan (sinchronies) ondersoek en geanaliseer het. Daarvoor moet ' $n$ teks eers afgegrens en struktureel ondersoek word sodat sy inhoud binne hierdie dissipline ter sprake kan kom. Dit heet teks-immanente werk, daarna kom die historiese arbeid by. Indien die volgorde omgekeer word, ontstaan die moontlikheid dat dinge buite die teks die inhoud bepaal. Werk die homileet met die verskillende metodiese fases, word ' $n$ kontrolesisteem outomaties in die werkwyse ingebou en op die wyse word die homileet gedissiplineer om telkens te hertoets wat hy reeds gedoen het ${ }^{25}$.

Indien 'n homileet 'n teks so deurgewerk het, kan hy met reg 
daarop aanspraak maak dat hy alle middele tot sy beskikking aangewend het om vas te stel wat daar in die teks staan. 'n Metode is nie verabsoluteer nie en daar is erns gemaak met die twee vernaamste perspektiewe wat die nuwere linguistiek geopen het: Konteks is verdiskonteer, want sinchronie is voor diachronie beoefen.

\section{PREEKVOORBEREIDING IN DIE PRAKTYK}

'n Kommunikatiewe verwerking van die preektema akkommodeer nie die tegniese data uit die wetenskaplike voorarbeid nie (dan is so 'n preekpoging 'n lesing); inteendeel, 'n dialogies-kommunikatiewe preek wil naamlik so oor Jesus, sy werk en diens praat dat dit eintlik Hy self is wat aan die woord kom in die preek. Die preek moet dus, wat inhoud en vorm betref, so voorberei en gestruktureer word dat die Woord werklik aan die woord kan kom ${ }^{26}$.

Aanvaar die homileet dit as uitgangspunt dan word die metodepluralisme in sy preekvoorbereiding verantwoord. Die vraag pretendeer egter in watter mate geskied die werkmetode in die praktyk.

\subsection{Literêre arbeid}

Vanweë die tydrowendheid van hierdie onderneming word dit meestal agterweë gelaat in die preekvoorbereiding. Die teks word woord vir woord verklaar en 'n vertaling sien die lig waarin hoofgedagte gelykgeskakel word met die bygedagte. As gevolg van dié vertaling en literêre arbeid word 'n toepassing bygevoeg wat meestal 'n geforseerde afdaling ${ }^{27}$ van die teologiese uiteensetting na die menselewe is.

Die problematiek word verder gekompliseer deur die onverantwoorde metode van eksegese wat geen bevredigende resultate lewer nie. Kommentare word ingespan en die literêre arbeid word al minder ' $n$ eie arbeid ${ }^{28}$ van die homileet wat tot gevolg het dat sy onvermoë om die grondtaal te gebruik gemaksimaliseer word.

Tereg pleit geleerdes vir selfstandige eksegese, maar vanweë die veeleisendheid van gemeentewerk kom dit nie altyd tot sy reg nie. Dit is my oortuiging dat die nuwe semantiese woordeboek en kommentare van die formaat wat deur J.P. Louw ${ }^{29}$, Newman en Nida ${ }^{30}$ geskryf is, voortreflike hulpmiddels kan wees sodat hierdie aspek van die voorbereiding van die preek sy regmatige plek kan verdien.

(Sien byvoegsel: 'n Voorbeeld van die Semantiese veld-Lexicon (Grieks)). 


\subsection{Homiletiese arbeid}

Volgens navraag en deur empiriese waarneming besit baie homilete van ons Kerk meer homiletiese kommentare as literêre kommentare. Dit impliseer dat ' $n$ denkfout begaan word wanneer' $n$ preek voorberei word. Die homileet raadpleeg uit die staanspoor die homiletiese kommentaar om ' $n$ tema te bepaal en daarna word ' $n$ Kittel-vertaling waarskynlik gebruik om ' $n$ bestaande vertaling te verifieer.

Hiervolgens kom weinig van die homileet se literêre arbeid tereg. Nadat hy die homiletiese kommentaar geraadpleeg het, is sy volgende stap meditasie (eerder: teologiese dinkwerk). Wat sê die Woord van God in hierdie teks vir my en die wêreld? Met ander woorde die volgorde word omgekeer - inteendeel, van analitiese literêre arbeid kom min tereg.

Die gebruik van homiletiese kommentare het dié verdere nadeel dat dit preekstof verskaf wat nie altyd tred hou met die sintetiese eis van die preekvoorbereiding nie. Sommige homiletiese kommentare se teologiese dinkwerk is subjektief, anti-Suid-Afrikaans, proWRK. ${ }^{31}$

\subsection{Gemeente-organisasie}

Indien die preekvoorbereiding so deurmekaar en afgewater is soos ek dit beskryf het, en as veeleisende metodes van eksegese die enigste teologiese oplossing bied, is dit menslik en verstaanbaar dat homilete die problematiek sal vermy en die weg van die minste weerstand sal volg. Die een weg is om jouself as predikant in die koorsagtige gejaag te werp, om 'n gemeente te "run". Dié besig wees $^{32}$ wat al 'n mens se energie dreineer en die illusie skep dat jy besig is om jouself op te gebruik in diens van die Koninkryk van God. Deesdae kan ons gerus die seminaar-manie hier byvoeg. Die prediker reis die wêreld vol in die week om hierdie seminaar en dan daardie seminaar by te woon. Meestal is die predikers passiewe deelnemers, maar vas oortuig dat hulle die "kerk in die wêreld" dien.

Maar ek wil nie veralgemenings maak nie, gevolglik my waardering vir predikers wat uitstekende administrateurs van hulle gemeentes is. Daarby word uitstekende indiensopleiding gebied in die seminare wat Kital aanbied, maar dit was ook my ervaring om seminare in die privaat sektor by te woon wat verbloemde Bacchusfeeste was. 
Dit is my oortuiging dat die prediker ' $n$ balans moet handhaaf tussen al sy aktiwiteite maar steeds die meeste tyd sal afstaan aan sy primêre taak ${ }^{33}, \mathrm{nl}$. om hom voor te berei om die Woord van God en daardeur die God van die Woord aan die gemeente te verkondig ${ }^{34}$.

\subsection{Die tydsfaktor}

As opdrag aan en konstitutiewe element van die kerk, kan die prediking met reg die hartstuk van die kerklike lewe genoem word. Indien die tyd bereken word wat aan die preekvoorbereiding gewy word, toon die resultate dat in sommige gevalle die taak tot 'n Saterdagaand beperk is. Daarteenoor beweer Henck Jonker deeglike preekvoorbereiding vereis: "Voor dertig minuten preekwerk, dertig uur studie. Wie niet studeert, leeft op den duur op een zoutloos homiletisch dieët" ${ }^{\prime 34}$.

Indien dit waar is, kan die vraag tereg gestel word: "Waar vind ek daardie tyd?"

Vergun my om enkele gedagtes te noem wat na my mening die probleem kan verlig.

\subsection{Indiensopleiding}

4.5.1 Die kursusse wat reeds deur verskeie departemente ten opsigte van die nuwere taalkunde aangebied is, het 'n redelike mate van sukses. Faktore wat bywoning beïnvloed, is waarskynlik koste en afstand. Indien seminaar-leiers die kursusse op 'n streekgrondslag aanbied sal die getalle waarskynlik toeneem, daarby sal kleingroepe die onderwerp beter deurwerk.

4.5.2 Korrespondensie

Vanweë afstand en die uitgestrektheid van ons land kan korrespondensiekursusse deur veral die Teologiese Fakulteit oorweeg word. Die administrasie van so 'n werkwyse skep egter probleme, maar ' $n$ oplossing is moontlik te vind in die administrasie van Kital.

\subsection{Preekwerkgroepe}

Deeglike eksegese van 'n Bybelgedeelte kan deur 'n groep predikers onderneem word, om eerstens 'n postille daar te stel en tweedens om 
weekliks in byeenkomste binne ring- of streekverband mekaar wedersyds te stimuleer tot geslaagde voorbereiding van preke.

Sameroepers van sodanige preekwerkgroepe kan desnoods deur die Fakulteit toegerus word om op hulle beurt weer kollegas in hulle omgewing toe te rus.

\subsection{Preekbeurte}

Indien die aanbeveling van Henck Jonker nagevolg word ten opsigte van die tyd wat aan preekvoorbereiding afgestaan moet word, word dit 'n homiletiese onbegonne taak om twee verskillende preke op dieselfde Sondag vir dieselfde gemeente voor te berei.

Die gemeentes wat twee eredienste hou op 'n Sondag sal dalk moet aanvaar dat die naburige prediker by die tweede diens sal optree. Die wisselwerking sal in baie gemeentes waarskynlik aanleiding gee tot 'n hoër bywoningsyfer van die tweede erediens. Die werkwyse bring dan mee dat die homileet 20-30 uur per week aan studie kan afstaan wat sekerlik nie te veel gevra is, veral indien dié studie ook vrugbaar aangewend kan word in die kategese en die pastoraat.

\subsection{Inskakeling van die gemeente}

In die voorbereiding van ' $n$ preek is daar bepaalde beslissings wat 'n homileet alleen moet maak, maar daar is tog keuses wat die beslissings kan beïnvloed. Die gemeente speel ' $n$ beduidende rol want ' $n$ goeie prediker sal nooit wêreldvreemd probeer preek nie. Indien 'n klein groep lidmate betrokke raak by die predikant se preekwerk mag daar dalk begrip kom vir die taak, dit sal beslis 'n oorgang wees van meeleef na meedoen. Die bedoeling is egter nie om 'n elite-klubom-die-dominee op te bou nie; inteendeel, so 'n werkgroep het as taak om die prediker ' $n$ beeld te gee van hoe 'n kerkganger luister. Die werkgroep kan ook korreksies aanbring op die prediker se voorstelling van die leefwêreld van sy lidmate. Eksegese van 'n teks kan dien as inhoud vir Bybelstudie wat saam met die predikant deur die groep onderneem word - studeerkamerwerk kan dan so deurgegee word in plaas van om dit vanaf die kansel oor te dra. Die moontlikhede van so 'n werkgroep is legio, gevolglik neem ek die vrymoedigheid om die werk van J Thomas, Het luistert Nauw $w^{35}$ baie sterk aan te beveel. 


\subsection{Slot}

Die prediking as een van die gestaltes van die verkondiging is nie in die eerste instansie ' $n$ daad van die mens nie. Dit kom van God. Die kerk se daad begin eers wanneer die "Reichsgotteswirke Gottes" aan hom bekendgemaak is ${ }^{36}$, maar ook dan bly die kerk gebonde aan die Woord. Die kerk moet weet dat hy by die prediking sy uitgangspunt onvoorwaardelik in die Heilige Skrif as enigste bron moet neem en homself by die Skrif as laaste norm moet neerlê. Dit gaan dus in die prediking daarom dat die één Woord van God verkondig sal word. Só moet die kerk sy taak en opdrag met betrekking tot die prediking verstaan. Anders gesê, in die primaat van die Woord in die kerk, is die primaat van die prediking gegrondves.

\section{Verwysings}

1. JI de Wet, Diktaatlesings, Prinsipiële Homiletiek, UP, 1982, 19.

2. JI de Wet, Is Eksegese Prediking, UP, 1980, 1.

3. Ibid, 1.

4. AG van Aarde, Moderne Semantiek en Formele Homiletiek, Hervormde Teologiese Studies, Jaargang 34, Afl. 1 en 2, 52.

5. DJ Booysen, Die keuse van ' $n$ teks vir die prediking, Die Hervormer, Aug. 1977, 4.

6. L Fendt, Homiletik, Walter de Gruyter, Berlin, 1970, 13-16.

7. GE Sweazey, Preaching the Good News, Prentice-Hall, New Jersey, 1976, 33.

8. SGA Golden, Dialogies-Kommunikatiewe Prediking, ongepubliseerde DD Proefskrif, UP, 1982, 198, 201-202.

9. JI de Wet, aw., 1980, 9 .

10. Heribert Arens, Kreativität und Predigtarbeit, Claudius Verlag, Munchen, 1977, $17-22$.

11. "Deur analise word die verskillende gedagtes wat die teks bevat, te voorskyn gebring. Na sorgvuldige eksegese van die teks word die hoofinhoud van die teks vasgestel en geformuleer. Uit hierdie materiaal wat die prediker uit die Skrif versamel het, bou hy dit uit tot ' $n$ organiese geheel, waarin ooreenkomstig die bedoeling van die teks elke gedagte sy toekomende plek kry ... Die dele van die teks word as dele van die tema (ons sou praat van die hoofgedagte of kerugmatiese spits) gesubordineer en daarmee organies verbind ... Die preek rus op die eksegese van die gehele teks en van elk van sy onderdele. Dit is expositio et applicatio verbi Dei." Vgl. T Hoekstra, Gereformeerde Homiletiek, Zommer et Keuning, Wageningen 393. Soos aangehaal deur JJ de Klerk, Prediking, NG Kerk Boekhandel, Pretoria, 1977, 109.

12. BA Müller, Die eksegetiese onderbou van die Struktuur van die prediking "Sol Iustitiae", deur PA Verhoef e.a., NG Kerk-Uitgewers, Bloemfontein.

13. Vgl. G Ebeling, Theologie und Verkundiging, Tubingen, 1967, 14, 15, 65, 80; G Ebeling, Wort und Glaube, Tubingen, 1969, 344 asook Wort und Glaube II, 425-426, soos aangehaal deur HJC Pieterse, Skrifuerstaan en Prediking, NG Kerkboekhandel, Pretoria, 1979, 101-112.

14. Vgl. JJ de Klerk, aw., 105.

15. JI de Wet, aw., 1980, 6. 
16. Ibid, 7 .

17. Ibid, 8.

18. AG van Aarde, Moderne Semantiek en Formele Homiletiek, Heroormde Teologiese Studies, Jrg. 34, Afl. 1 en 2, 54.

19. JI de Wet, Die dienskarakter van die prediking, Hervormde Teologiese Studies, Jrg. 32, Afl. 3 en 4, 109-110.

20. Il de Wet, Diktaatlesings, Prinsipiële Homiletiek, 1982.

21. AG van Aarde, aw., 53-54.

22. JA Loader, Gedagtes oor gekontroleerde eksegese, Hervormde Teologiese Studies, Jrg. 34, Afl. 1 en 2, 3 en 5.

23. Ibid, 6 ,

24. Ibid, 11.

25. Ibid, 6 en 8 .

26. SGA Golden, aw., 202.

27. H. Jonker, En toch preken, Callenbach, Vijkerk, 1973, 139.

28. Vgl. Helmut Thielicke, Leiden an der Kirche. Ein persönliches Wort, Furche-Verlag H. Rennebach KG, Hamburg, 1965, 25.

29. Vgl. JP Louw, A Semantic Discourse Analysis of Romans, Vol. I and II, UP, 1979.

30. Vgl. BM Newman and Eugene A. Nida, A Translators' Handbook on Paul's letter to the Romans. UBS New York, 1973.

31. Vgl. E. Lange, Die ökumerische Utopie, oder: Was bewegte die ökumesche Bewegung Stuttgart/Berlin, 1972, asook HM Kuitert, Zonder geloof vaart niemand wel, Ten Have, Baarn, 1974, 40 veral $43-47,66-77,78-93$.

32. Volgens geleerdes is die "ek-is-verskriklik-besig"-sindroom, 'n simptoom van akute depressie.

33. Hierdie opdrag aan die kerk om te preek, gee 'n heel besondere plek aan die prediking in die erediens van die gemeente. Die prediking kan dus gesien word as die primêre gestalte in die hele struktuur van die kerklike verkondiging. Ons stem met De Klerk saam wanneer hy sê: "In diens van die kerk, wat in haar midde en op las van Christus en in sy Naam vervul word, neem die prediking van die evangelie, of as $u$ wil, die bediening van die Woord, die eerste plek in." As opdrag aan en konstitutiewe element van die kerk, kan ons nou met reg die prediking die hartstuk van die kerklike lewe noem. Vgl. SGA Golden, aw., 136-137.

34. H. Jonker, Actuele Prediking, Callenbach, Nijkerk, 2de druk, 233.

35. J Thomas, Het Luistert Nauw, JH Kok, Kampen, 1978.

36. Vgl. L Fendt, Homiletik, Walter de Cruyter, Berlin, 1970, 6. 